\title{
ŞEYH ABDURRAHMAN'A GÖRE NAKŞBENDÎLİĞİN ONBİR TEMEL ESASI
}

\author{
BY SHEIKH ABDURRAHMAN ELEVEN NAQSBENDIH BASIC FACTS \\ Murat ÖZAYDIN ${ }^{1}$
}

\section{$\ddot{O} \mathbf{z}$}

Ehl-i Sünnet akidesine sıkı sıkıya bağlı olmak, ruhsatı bırakıp azimetli olmak, murakabeye devam etmek, daima Hakk'a yönelik bulunmak, dünya pisliklerinden uzak kalmak, Allah'tan başka her şeyden kaçınmak, huzur alışkanlığı kazanmak, Allah'ı zikre gizli olarak devam etmek, zikir esnasında Kerim olan Allah'tan bir nefes bile gafil olmamak için nefes alışverişte kendini kontrol etmek, en büyük ahlakın sahibi olan Hz. Peygamber (s.a.v.) ahlakı ile ahlaklanmak için Abdulhâlik-i Ğucduvânî’nin ortaya koyduğu on bir esası uygulamak şarttır. Bu yolda ilerleyen her kemale sahip olur. Gizli hal ve neşeli gönülle huzuru bulur. Korku, sapıtma ve tehlikelerden emin olur. Hakka kavuşmanın sevinci ile her daim huzurlu olur.

Nakşî-Hâlidî silsilesinden gelen tüm mutasavvıflar bu prensipleri esas alarak şöyle der; Tasavvuf'un aslı, Kur'an ve Sünnet yolunda yürümektir. Tasavvuf; üstadlarının tarif ettiği yoldan, ne olursa olsun ayrılmamaktır. Bid'atleri, boş arzuları ve nefsani istekleri terk etmektir. Hürmet gösterilmesi gereken büyük zatlara ve diğer mahlukata karşı sayg1 da kusur etmemektir. İşte tasavvufun aslı ve özü budur. Kim bu yoldan saparsa, muhakkak o Hak erleri makamından düşmüş olur. Kendilerini gizlerler, kalplerinden ise vahdet yolunu izlerler. Bedenlerini halka, kalplerini Hakk'a teslim ederler. Bu yol ile gizlice Hakk'a doğru giderler. Dışardan yabancı, içerden aşina olurlar. Onlar bu yol ile hatıralarını yok ederler. Yaptıklarını ise hep gizli yaparlar. Muhabbetlerinin gizliliğini halk bilemez. Kalplerinin zevkine hiç zarar gelmez. O halde onlar, şöhret afetinden uzak ve Allah-u Zülcelal'in evliyasının seçkinleri olurlar. Bu çalışmamızda yukarıda ana hatlarını zikrettiğimiz hususlarda Ğucduvânî ve Aktepe'den örnekler verilmek suretiyle, on bir esasın tanımları başta olmak üzere konu en güzel biçimde ifade edilmiş ve Nakşî yolunda ilerleyen bir sâlikin nefsini terbiyede vazgeçilmez prensipler olduğu sonucuna varılmıştır.

Anahtar kelimeler: Nakşbend, Ğucduvânî, Aktepe, Nefs. Mutasavvıf.

\begin{abstract}
Abdulhalik-i Ğucduvânî' has introduced 11 important points in order to comply with the heavenly morals of the last Prophet Mohammed (sas) consisting of the following: to be tightly linked to Ahl al-Sunnah, belief, creed, being willing to obey his dogma, being supervising, being always turned to God, keeping away from venial sin, avoiding anything other than God, being peaceful, never give upraising God, praying to God and always being aware of the fact that only with his permission we are allow to breath. Following this path one would reach perfection. The happiness of finding God will enwrap you with peace.

All Sufis who are supporters of the Naqsh-Halide take those basis to heart and declare: the real Islamic Sufism is to obey the Quaran and the sunna. Never leave the path shown by the masters of Islamic Sufism. They strictly underline that one should keep away from secular and lustrous things. Showing respect to important religious men as well as to other creatures. This is the basis and only truth of Sufism. Leaving this path would mean leaving the maqam of the religious men. Sufis hide their identity but know each other from the heart. Their bodies belong to the world but their hearts belong to God. This path brings them to God. They alienate from the world and be familiar to the sprit. This forgets about the past. Their prayers are always kept as a secret. The people do not know their heavenly conversation. The peace and the joy in their hearts are always present. Thus they are far away from secular affairs but they are the chosen people. This study aims to explain and underline the most important steps which are needed to be a successful follower of the religious belief with the help of important examples provided by Gucdavini and Aktepe.
\end{abstract}

Keywords: Naqshbend, Ğucduvani, Aktepe, Nafsh. Sufish.

\footnotetext{
${ }^{1}$ Yrd.Doç.Dr., Dicle Üniversitesi İlahiyat Fakültesi, mozadin@dicle.edu.tr
} 


\section{ŞEYH ABDURRAHMAN'A GÖRE NAKŞBENDÎLİĞIN ONBİR TEMEL ESASI}

İslam tasavvufunda çok derin, çok faydalı, çok hikmetli prensipler vardır. Bunlar Nakşbendîliğin onbir esası olarak bilinir. $\mathrm{Bu}$ esas ve prensipler Nakşî tarîkatının büyüklerinden Abdulhâlık-1 Ğucduvânî hazretlerinin kısaca formüle ettiği kelimelerdir. Bu esasları Şâh-1 Nakşbend hazretleri ihyâ etmiş, tarîkata yerleştirmiştir. Bu esasları ifade eden kelimeler; Hûş Der Dem, Halvet Der Encümen, Nazar Ber Kadem, Sefer Der Vatan, Yâd Kerd, Bâz Geşt, Nigâh Daşt, Yâd Daşt, Vukûf-ı Zamanî, Vukûf-ı Adedî, Vukûf-ı Kalbı̂’dir. Bu kelimelerin çeşitli tasavvuf kitaplarında izahları yapılmıştır.

Biz bu çalışmamızda ilk olarak bu prensipleri ortaya koyan Abdulhâlik'i Ğucduvânî hazretleri ve konu başlığımız olan Abdurrahman Aktepe hazretleri hakkında bilgi verdikten sonra, bu onbir temel prensibi Abdurrahman Aktepe hazretlerinin de görüşleriyle birlikte sunmaya çalışacağız.

\section{A. ABDULHÂLİK-İ ĞUCDUVÂNî}

Buhâra’ya yaklaşık 30 km. uzaklıktaki Ğucduvân köyünde doğdu, (/617/1220) yılında vefat etti. Risâle-i Sâhibiyye adlı eserinde anlattığına göre babası, İmam Mâlik neslinden, zâhirî ve bâtınî ilimlere vâkıf bir âlim olan Malatyalı Abdulcemil İmam'dır (Ğucduvânî, 9596). Düşmanları tarafından şehirden çıkarılan Malatya sultanının tahtına dönmesini sağlayan Abdulcemil, 113 yaşında olmasına rağmen mükâfat olarak sultanın kızıyla evlendirilir. $\mathrm{Bu}$ arada Hızır, Abdulcemil'e bu evlilikten bir erkek çocuğunun doğacağı müjdesini verir ve adını Abdulhâlık koymasını ister. Ğucduvânî, sebebini açıklamadığı bir husustan dolayı bir müddet sonra babasının Malatya'dan ayrılmak mecburiyetinde kaldığını ve Buhâra'ya giderek Gucduvân köyüne yerleştiğini, kendisinin burada dünyaya geldiğini kaydeder.

Yetişme çağında tahsil için Buhâra'ya giden Abdulhâlık, şehrin önde gelen âlimlerinden İmam Sadreddin'in yanında tefsir okurken. "Rabbinize yalvara yakara ve gizlice dua edin. Bilin ki O haddi aşanları sevmez." (el-A'raf, 7/55) mealindeki âyetin yorumu sırasında buradaki "gizlilik” le ilgili bir tereddüdünü ifade eder. Şöyle ki: Eğer zâkir yüksek sesle zikreder veya zikir esnasında organlarını hareket ettirirse dua veya zikirden başkaları haberdar olur. Öte yandan sırf kalbiyle zikrederse bundan şeytan haberdar olur. Çünkü hadiste bildirildiğine göre şeytan insanoğlunun içinde damarlarındaki kan gibi akıp durmaktadır (Buhârî, Ahkâm, 21). Ğucduvânî, bu durum karşısında âyetteki duayı gizlice yapma emrinin nasıl yerine getirileceğini, diğer bir ifadeyle zikr-i hafînin nasıl uygulanacağını sorunca hocası Sadreddin, ilm-i ledünne ait olan bu meseleyi ileride ehlullahtan bir zâtın kendisine 
öğreteceğini söyler. Nitekim kısa bir müddet sonra Ğucduvânî’nin Hâce Hızır diye andı̆̆ı, doğumundan önce de kendisiyle ilgilenen Hızır gelerek ondan havuza dalmasını, suyun altında iken kelime-i şehâdeti tekrarlamasını ister ve ona zikr-i hafînin usûlünü telkin eder. Aynı zamanda zikrin sayılarak yapılacağını belirten Hâce Hızır, böylece bütün Hâcegân'ın ve onlardan sonra Nakşbendîler'in benimsedikleri vukûf-1 adedî prensibini de ortaya koymuş olur (Ali Safî, 1256: 30). Harîrîzâde, Ğucduvânî'nin suyun altında iken yaptığg zikir sırasında kendisinde el-cezbetü'1-kayyûmiyye denilen çok kuvvetli bir cezbe hâsıl olduğunu kaydeder (Harîrizâde, I, vr 378b.).

Ğucduvânî, yine kendi ifadesine göre, yirmi iki yaşına kadar onu manevî evlât edinen Hâce Hızır'ın terbiyesi altında kaldıktan sonra Buhâra'ya gelen meşhur fakîh ve mutasavvıf Yusuf el-Hemedânî’nin (ö.535/1140). müridleri arasına katıldı. Bazı kaynaklara göre Hemedânî Buhâra'ya değil Semerkant'a gelmiş ve Ğucduvânî ona burada intisap etmiştir. Hemedânî'nin zikirde takip ettiği yol alâniyye (cehri) iken Ğucduvânî’nin Hâce Hızır'dan öğrendiği zikr-i hafîye devam etmesine izin vermiş, Hâce Hızır da Ğucduvânî'nin manevî terbiyesinin tamamlanmasını Hemedânî'ye havale ederek aradan çekilmiştir. Bundan dolayı Hâce Hızır'1 Ğucduvânî'nin pîr-i sebâk'1 (zikir telkin eden pîri) ve pîr-i irâdet'i (sulûke başlatan pîri), Hemedânî'yi de sadece onun sohbet pîri saymak gerekir (Lâmiî, 411).

Ancak Ğucduvânî'ye bir hırka verdiği için silsilede onun asıl mürşidi olarak Hemedânî yer almaktadır. Hemedânî, Buhâra'dan (veya Semerkant) ayrılıncaya kadar onun yanında kalan Ğucduvânî daha sonra memleketine döndü. Burada "sohbetine lâyık" bir kimse bulamayınca (Fazlullah, vr 86a) inzivaya çekilip riyâzet ve mücâhede dünyasına daldı. İnziva müddeti boyunca gösterdiği bazı kerametler sayesinde (vakit namazlarını kılmak için Mekke'ye gidip gelmek gibi) uzak yerlerde de meşhur oldu. Öyle ki Şam'da onun adına bir hankâh kuruldu. Burada oturan müridleri kendisini ziyaret etmek için Ğucduvân'a gelmeye başladılar ( Câmî, 1995: 384).

Hemedânî’nin biraktığı halifelerin üçüncüsü olan Ahmed Yesevî, Türkistan'da İslâmiyet'i yaymak için Buhâra'dan ayrıldığı zaman Ğucduvânî inzivasından çıkarak Buhara ve civarındaki dervişlerin başına geçti. Ğucduvânî'nin, halifesi Hâce Evliyâ-i Kebîr'e hankâhta oturmamasını tavsiye ettiği halde hayatının bu son dönemini Ğucduvân'daki hankâhta geçirdiği anlaşılmaktadır. Muînu'l-Fukarâ, aralarında meşhur Âl-i Burhân'dan âlim Muhammed b. Ömer es-Sadr'in da bulunduğu Buhâra'da ikamet eden müridlerinin her cuma gecesi onu ziyarete geldiklerini kaydeder (Târih-i Mollazâde, 46). 
Kaynaklarda Ğucduvânî’nin vefatı için muhtelif tarihler verilmektedir. Gulâm Server Lâhûrî, herhangi bir eski kaynağa dayanmadan onun 575'te (1179) vefat ettiğini söyler (Nizameddin Evliya, I, 530). Ğucduvânî, Necmeddîn-i Kübrâ'nın 618 (1221) yılında vukû bulan ölümünden az önce ve henüz Moğol istilâsı başlamadan vefat etmiştir (Ferheng-i İân, Zemîn, 1953: I, 70). Saîd-i Nefîsî bu kayda dayanarak Ğucduvânî'nin ölüm tarihini 617 (1220) olarak verir (Nefîsî, 16).

Rivayete göre Yûsuf el-Hemedânî gibi Ğucduvânî de dört halife tayin etmiştir: Hâce Ahmed Siddîk, Hâce Evliyâ-i Kebîr (Kelân), Hâce Habbâz Buhârî ve Hâce Ârif-i Rivgerî. Hâcegân silsilesi bunlardan sonuncusu vasitasıyla sürdürülmüştür.

Ğucduvânî'nin kelimât-1 kudsiyye olarak tanınan sekiz tarîkat prensibini ortaya koyması son derecede önemlidir. Hûş der-dem (alınan her nefeste gafletten uzak olmak), Sefer der-vatan (beşerî sıfatlardan sıyrılıp ilâhî sıfatlarla muttasıf olmak), Nazar ber-kadem [yürürken bakışlarını ayağından ayırmamak), Halvet der-encümen (zâhirde halkla, esasta Hak ile bulunmak), Yâdkerd (lisanı zikirle beraber kalbi zikri icra etmek), Bâzgeşt (zikir yaparken (ilâhî ente maksûdî ve ridâke matlûbî) "Allah'ım! Maksûdum sensin ve talep ettiğim senin rızandır." cümlesini söylemek), Nigâhdâşt (meşguliyet verecek düşünceleri defetmek) ve Yâddâşt (zikrin sebep olduğu uyanıklığı sürdürmek) prensiplerinden ibaret olan kelimât-1 kudsiyye, sonradan ilâve edilen üç prensiple beraber (vukûf-1 zamânî, vukûf-1 adedî, vukûf-1 kalbî) Nakşbendiliğin başlıca umdelerini oluşturmaktadır (Ali, Safî, 1256, 32-43). Ğucduvânî'nin asıl önemi Hâcegân silsilesini kurmanın da ötesinde ruhaniyet âleminde Hâce Bahâeddin Nakşbend'e zikr-i hafîyi telkin etmiş olmasıdır.

\section{B. ESERLERİ}

1. Risâle-i Sâhibiyye. Yûsuf el-Hemedânî'nin menkıbelerini anlatan ve kendi hayatına dair bilgiler veren eser Saîd-i Nefisî tarafından yayınlanmıştır (Ferheng-i İrân, Zemîn, 1953: I, 70-101). Harîrîzâde'nin Tibyân'ında da (Harîrîzâde, I. vr 379a-389b) yer alan eserin bir özetini İrec Efşâr neşretmiştir (Efşâr, 6-16).

2. Vesâyâ: ${ }^{2}$ Ğucduvâni, kısa bir âdâb risâlesi mahiyetindeki bu eserini halifelerinden Hâce Evliyâ-i Kebîr için kaleme almıştır. Risâlede cahil sûfilerden kaçınmak, şerîat ve sünnetten ayrılmamak, hâkimlerden uzak kalmak, mümkün mertebe evlilikten kaçınmak, hankâhta oturmamak, semâ ile fazla meşgul olmamak gibi öğütler verilmektedir. Buhâra'ya iltica eden İranlı Şâfii âlimi Fazlullah b. Rûzbihân, Ğucduvân şehrinin 918'de (1512) bir

\footnotetext{
${ }^{2}$ Bu eser Süleymaniye Ktp., Esad Efendi, nr. 3702/5'te kayıtlıdır.
} 
Safevî muhasarasından Ğucduvânî'nin ruhaniyeti sayesinde kurtulduğu inancıyla Vesâyâ'sına bir şerh yazmıştır ${ }^{3}$ (DİA, 1997: XIV, 169-171).

\section{SEYH ABDURRAHMAN AKTEPE HAZRETLERININ HAYATI}

Şeyh Abdurrahman hazretleri 1270/1854 ${ }^{4}$ yılında Diyarbakır iline bağlı Çınar ilçesinin Aktepe köyünde dünyaya gelmiş ve 29 Mart 1910 (Özaydın, 2009: 69; Korkusuz, 1997: 39) tarihinde burada vefat etmiş ve aynı köye defnedilmiştir.

Şeyh Abdurrahman hazretleri, şeyh Hasan-i Nûrâni hazretlerinin en büyük oğludur. Aslen Hakkari'li olan Nûrâni hazretleri Hakkari'den ayrılıp Diyarbakır'a gelerek, burada yakın civarlarda bulunan medreselerde eğitim görmeye başlar. Şeyhlik makamına ulaştıktan sonra Aktepe köyüne yerleşir. Burada kısa bir zaman sonra Aktepe medresesini açar ve öğrencilerin eğitimine başlar, çok kısa bir süre sonra medrese genişleyerek bölgeye hitap etmeye başlar, çok sayıda öğrenci yetiştirilir. Bölgede meydana gelen gelişmeler, İstanbul'da saraya kadar ulaşır ve o devrin Osmanlı padişahı Sultan Abdülmecit Han (1823/1861) hazretleri bizzat bölgeyi ziyarete gelir, güzel bir şekilde ağırlanır, padişah ziyadesiyle memnun olarak bölgeden ayrılırken, medreseye bir hediye olması adına Aktepe köyü ve çevresinde hayli fazla ve geniş bir araziyi şeyh hazretlerinin şahsında hibe eder ve hediye olarak hizmette kullanmaları adına kabul etmelerini ister. ${ }^{5}$ Şeyh hazretleri de hizmet adına bu hediyeyi kabul eder. Arazinin hibe edildiğine dair ferman ve berat yaşanan yağmalama olaylarında maalesef kaybolmuştur.

Şeyh Hasan hazretlerinin şeyh Abdurrahman başta olmak üzere, şeyh Muhammed Can, şeyh Muhammed Sirac ve şeyh Muhammed Nur olmak üzere dört oğlu vardır. Şeyh Abdurrahman hazretleri diğer üç kardeşi gibi ilk eğitimine babasının yanında başlar. Ancak şeyh Abdurrahman hazretleri diğer üç kardeşinden farklı olarak eğitimini tamamlamak için, Irak ve Suriye başta olmak üzere bölgedeki birçok medresede eğitim görür ve eğitimin

\footnotetext{
${ }^{3}$ Süleymaniye Ktp, Yahyâ Tevfik, nr. 1500. vr. 83a-102b.

${ }^{4}$ Başbakanlık Devlet Arşivlerinde Osmanlı Devleti nüfus kayıt defterlerinden alınan belgeden doğum tarihinin 1854 olduğu anlaşılmaktadır. Ayrıca Şeyh Hasan Nûrâni'de kendi eliyle yazmış olduğu bir vesîkada, tüm çocuklarının isimlerini ve doğum tarihlerini yazmış, bu belge günümüze kadar ulaşmıştır; Ayrıca Bkz: Korkusuz, Tezkire-i Meşâyihi Âmid, s. 38.

5 Şeyh Abdurrahman hazretlerinin torunu olan ve şu anda vekili bulunan Şeyh Şafi Efendi’den aldığımız bilgilere göre, Abdülmecid Han bölge ziyaretinden sonra, yaşadıklarından çok etkilenmiş, büyük bir feyz almış ve memnuniyetinin bir hatırası ve bir hediye olması münasebetiyle yazdığı bir fermanla bölgede Aktepe köyü ve çevresindeki geniş bir araziyi hibe etmiştir, bu belge uzun yıllar muhafaza edilmiş ancak, tarih sahnesinde meydana gelen yağmalama olayları sonucunda birçok kıymetli eserle birlikte bu belgede yok olmuştur. Bugün hala o yörede kullanılan ve bu aile tarafından işletilen araziler padişah hazretleri tarafından verilmiş arazilerdir. $\mathrm{Bu}$ da anlattıklarımıza bir delil teşkil etmekte ve desteklemektedir.
} 
başarıyla tamamladıktan sonra Aktepe'ye geri dönerek, babası Şeyh Hasan-i Nûrânî hazretlerinin vefatından sonra bir süreliğine medresenin eğitim sorumluluğunu üstlenir. Ancak şeyh hazretlerinin medrese eğitmenliği de tıpkı buradaki öğrenciliği kadar uzun sürmez, kısa vadeli olur. Bunun sebebine gelince, şeyh hazretleri kendini başka alanlara yönlendirerek, kitap ve makale yazmaya ağırlık verir. Sürekli babasının kütüphanesinde bulunan şeyh hazretleri bilimle ve kültürle iç içe bir yaşam sürdürür. Yaşamının büyük bir kısmını bu kütüphane de geçiren şeyh hazretleri, kendisini sürekli araştırmaya ve bu araştırmaların bir sonucu olarak bilim dünyasına ve İslam âlemine nitelikli eser, makaleler ve çeviriler kazandırmıştır. Bu yönü kendisini ziyarete gelen herkesin dikkatini çekmektedir. Şeyh hazretleri müderrisliğin eğitimini "Leyl-u Mecnûn” adlı eserin sahibi şeyh Muhammed Can’a devretmiştir. Şeyh Muhammed Can'da bu görevi yaşamının son anına kadar başarıyla icra etmiştir.

Şeyh Abdurrahman hazretleri birçok eser kaleme almış, ancak bu eserlerden birçoğu çeşitli sebeplerden ötürü kaybolmuş, günümüze ulaşamamıştır. Şeyh hazretlerinin şu anda sağlam olarak 13 eseri mevcuttur. Bu on iki eserinin dışındaki eserleri, ya bakımsızlıktan ya da âlimlerin kütüphaneden alıp geri getirmeyişlerinden ve bir takım sebeplerden dolayı günümüze ulaşamamıştır. Bu duruma en güzel örnek, şu an Konya il müzesinde Aktepeli’ye ait yazma eser $^{6}$ ve Diyarbakır kültür müdürlüğünde kayıtlı bulunan yaklaşık 250 kadar yazma eserdir.

Şeyh hazretlerinin eserlerinin başlicaları; Ravdu'n-Naîm, Dîvâna Rûhî, Kitâbu'l-İbrîz, Keşfu'z-Zelâm, Diyarbakır'a Özgü Takvim, Astronomi Kitabı, Astronomi Kitabı çevirisi, F1kıh üzerine bir eser, Arapça Gramer üzerine bir çalışma, hastalıklar için şifâ kitabı ve Tarîkat ehli olanlar için yazmış olduğu “Risâletu'l-Edeb ve'l-Âdâb adlı eseridir.

\footnotetext{
${ }^{6}$ Bu bilgiyi Şeyh Şafii Efendi'den aldık. Kendileri, ilk olarak İzmir Emniyet Müdürlüğünde Başkomiser olarak görev yapan bir aile dostlarının şeyhin torunlarından Necat Efendi'yi aradığını ve burada şeyh Abdurrahman hazretlerine ait bir eser bulunduğunu bildirmiş, müracaat ederek bu eseri kendilerine verilmek üzere müracaat etmelerini istemiş, ancak Necat Efendi Şeyh Şafii Efendi'yi biraz geç haberdar etmiş, yapılan müracaat sonucunda eserin İzmir'den Konya Kütüphanesine gönderildiğine dair bir bilgi verilmiştir. Şeyh Şafii Efendi daha sonra Konya Kütüphanesiyle görüştüklerini ilk önce olumlu bir yanıt aldıkları ancak daha sonra müdürün değişmesi sebebiyle girişimlerinin sonuçsuz kaldığını belirttiler. Bu bilgilere ulaştıktan sonra bizzat kendim Konya Kütüphaneleriyle irtibata geçtim. Kütüphanelerinde böyle bir eserin mevcut olup olmadığını sordum. Ancak kütüphane yetkilileri yazılı olan eserlerde böyle bir bilgiye ulaşmadılar. Ancak ellerinde açılmamış ve kayıtları yapılmamış 2000'den fazla eser bulunduğunu bunlar hakkında da bir bilgileri olmadığını dile getirdiler. Şeyh Şafii Efendi eserin muhtevası hakkındaki bilgileri de tarafıma ilettiler. Şeyhin ifadesine göre, eser "Tıbb-i Nevevî" şeklinde kaleme alınmış. Eserde tabiatta bulunan bitkilerin hangi hastalığa faydalı olduğu ve bir çok hastalıkların tedavisiyle ilgili açıklamaların yapıldığı önemli bir eser olduğu hakkında bilgiler verdiler, ancak ellerine ulaşamamanın derin üzüntüsünü yaşadıklarını da açık bir ifadeyle dile getirdiler.
} 


\section{NAKȘBENDÎLİĞİN ONBİR ESASI}

Ehl-i Sünnet îtikâdına bağlı olan Nakşbendiyye tarîkatı çeşitli ilimlerle meşgul olmaya, va'z ve sohbetler vasitasıyla bu ilimleri tebliğ etmeye son derece önem vermiştir. İlimle meşgul olmanın, pozitif ilimlerden, bilhassa fizik, kimya, biyoloji vs. gibi Hakk’ın kudret ve azâmetini idrake vesile olan ilimlerden faydalanmanın bir çeşit zikir olduğunu kabul etmiştir.

Bir de Nakşbendiyye tarîkatı mensupları, Şerîat esâslarına uymaya ve ona bağlı olmaya son derece önem vermişlerdir. Şeyh Ahmed Farûkî'nin; “Şer'î edeplerden birine riâyet, mekruhlardan birini bırakmak; zikirden, fikirden, murakabeden ve mertebelere teveccühten daha faziletlidir.” (Abdullah Hânî, 1976: 13) şeklindeki açıklamaları, bu durumu açıkça ortaya koymaktadır.

Ayrıca Nakşbendiyye tarîkatı, boş kalan insanların nefsin pençesinden, çeşitli kötü alışkanlıklardan korunması için, tevbe, istiğfar, zikir, tefekkür, nâfile namazlar ve benzeri şeylerle meşgul olmayı tavsiye etmiştir. Bu şekilde nefsi yenip kalbi kontrol altında tutmaya murâkabe denir.

Nakşbendiyye tarîkatı, "Kelimât-1 Nakşbendiyye" ya da "Kelimât-1 Kudsiyye" olarak ifade edilen onbir prensip üzerine bina edilmiştir (Şimşek, 2004. 315). Abdulhâlik-i Ğucduvânî'nin tesbit ettiği şu on bir prensip, Nakşbendiyye Tarîkatı'nın esasını teşkil etmektedir. Burada önemli bir hususu belirtmekte fayda vardır. Farsça olan sekiz prensibi, Ğucduvânî ortaya koymuş, Arapça olan üç prensib ise Bahâuddîn Nakşbend tarafından bina edilmiştir (Tokâdî, no. 772: vr. 38b).

1- Vukûf-1 Zamânî: Müridin zamanı çok iyi değerlendirmesidir.

2- Vukûf-1 Adedî: Dersin adedi ve gerçek manası düşünülmelidir.

3- Vukuf-1 Kalbî: Kalbi uyanık tutmak gerekir.

4- Hûş der-dem: Nefes alıp verirken, gaflette olmamak.

5- Nazar ber-kadem: Başkasına değil, kendine bakmalıdır.

6- Sefer der-vatan: Halktan ayrilıp Hakk'a gitmesidir.

7- Halvet der-encümen: Halk içinde de olsa, halvet hali olmalıdır.

8- Yâdkerd: Şeyhin verdiği zikri, kalb ve dil ile daima tekrarlamak.

9- Bâz geşt: Zikirle Allah'a dönüş, vuslat düşünülmelidir. 
10- Nigahdâşt: Kalbi zararlı düşüncelerden korumak.

11- Yâddâşt: Masivâyı bırakarak, sadece Allah'ı düşünmektir (Kara, 1987: 156).

\section{YÂD KERD}

Farsça'da zikretmek, hatırlamak demektir. Murâkabe mertebesine ulaştıktan sonra, muaayen sayıda nefy ve isbât (la ilahe illallah) zikri yapmaktır. Bu şekilde kalbin pası giderilir ve müşâhedeye ulaşılır (Cebecioğlu, 2005: 706-707).

Nakşbendî tarîkatında, yolun edeplerini oluşturan bu kelimelerden ilki "Yad Kerd"dir. Bu kelime, Hâcegân'a göre, Tevhid kelimesini (La ilahe illallah) "haps-i nefes" ile zikretmekten ibarettir. Nakşî tarîkatının mürşîdleri, sâliklerinin kalbini temizlemek için, tevhîd kelimesini haps-i nefes ile telkin edince; "Yâd kerd'e meşgul ettik” derlerdi. Bu bakımdan yâd kerd kelimesi, bu tarîkatta tevhîd kelimesini haps-i nefes ile zikirden kinâye olarak anılmıştır. Burada asıl amaç Sâlik'in dil ve kalp zikri ile sırr-1 tahkiki elde etmesidir (Tokâdî, 772, vr. 39b; Tokâdî, 772, vr. 13a; Tokâdî, 1018, vr. 11b; Semerkandî, 1273: 13).

Hâcegân Hazretleri buyurmuşlar ki : "Sâlik, yâd kerd ile meşgul olunca, yani haps-i nefes ile zikre başlayınca, buna devam etmesi gerekir. Kalp nurlanmasına engel olan perdeler giderilip, beklenen nurlanmalar ve bunların işaretleri belirinceye kadar, aralıksız olarak zikre devam edilir. Nitekim bir hadîs-i şerifte şöyle buyrulmuştur. "Muhakkak ki kalpler durduğu yerde demirin paslandığı gibi paslanır. Onun cilası Yüce Allah’1 zikirdir.” (Beyhâki, I, 396, $522)$.

Yâd Kerd, Kalbin zâkir hale gelmesidir. Nefy-u İsbât yoluyla "Lâ ilâhe illallah" zikriyle kalpte bir nevi put haline gelmiş bulunan bütün mâsivâ kirleri çıkarıldıktan sonra, yegâne maksûdun Allah olduğu fikrinin kalpte sabitlenmesidir (Topbaş, 2006: 237).

Kalbe cila veren zikirler içerisinde tevhîd kelimesinin zikri başta gelir. Tevhîd kelimesi, nefy ve isbât'tan oluşmuştur. Nefy ile kalbin pası silinir, isbât ile de cilası verilir. Yani "Lâ ilahe" lafzı ile kalpteki pas atılır. "İllallah" lafzıyla da cilası çekilir. Pası silinip cilası yapılan bir kalpte tecelliler birbiri ardınca gelmeye devam eder.

Yâd kerd, şuur altına veya insanın özüne (ruhuna) Allah fikrini yerleştirmektir. Devamlı zikir halinde olmakla Allah-u Teâla'yı şuur altına, özüne yerleştiren kişinin hareketlerine, Allah'a ait güzel ve mükemmel ahlâk kabiliyeti nispetince yansır. Böylece o kişi, Allah-u Teâlâ da ki özellikleri yansıtan kişi haline gelir (Aktepe, 14). 
Kelime-i tevhîd'in "Nefy-u isbât" zikrinin, murâkabe dersi esnasında söylenişinde gözler yumulur, dil dimağa yapıştırılır ve nefes tutularak, kalp ile bir nefeste yirmi bir adet okunur. Böylece sâlik, murâkabe halinden müşahede mertebesine yükselir.

Tevhîd'in iki mânâsı vardır:

1. Zâhirî Tevhîd: "Lâ ilâhe illallah", Allah’tan başka ilâh yok.

2. Bâtınî Tevhîd: “Lâ mevcûde illallah”, O’ndan başka mevcut yok.

\section{VUKÛF- I ADEDÎ}

Arapça, sayıya dikkat etmek demektir. Zikirde sayı önemlidir. Sayının az ve ya çok olması, ruhun manevi gelişimine ters etki etmesi bakımından sayıya tam anlamıyla uymak gerekir (Cebecioğlu, 2005: 703).

Tarîkat edeplerinden ikincisi, "Vukûf-1 Adedî”dir. Bu kelime, tevhîd kelimesini haps-i nefes ile zikrederken, iki nefes arasını tekler üzerinde tutmaktır. Yani haps-i nefes sırasında üç, beş, yedi, on bir, on üç gibi tek adetler üzerinde bırakmaktır. İki nefes arasında tekli ve belli miktar üzerinde durmanın faydası, kalbi dağınıklıktan kurtarmak ve zikri huzurla yapmak içindir. Yoksa tekli miktarda durmak, haps-i nefeste şart değildir. Sâlikler arasında ikiliğe bile sebep olabilir. Bu hususa özellikle dikkat etmek gerekir.

Zikirde her ne kadar evveliyetle keyfiyet mühimse de, zikrin kemmiyeti, yani muayyen bir hudûdu ve ölçüsü olmadığı zaman bazen zihnî ve kalbî huzursuzlukların görülmesi de muhtemeldir. Bu durum her şeyde olduğu gibi zikirde de ifrât ve ölçüsüzlükten doğabilecek hataların bir neticesidir. Bu sebeple zikri hem keyfiyet ve hem de kemmiyet itibariyle en güzel bir sûrette îfầ etmeye gayret gösterilmelidir. Zîrâ zikirde sayıya riâyet, mücerred olarak sayı saymak değil, sayı çerçevesi içinde "kalbî zikri" derinleştirmektir (Topbaş, 2006: 239).

Hâcegân Hazretlerinin "Tek üzerinde durma, yirmi bir adede ulaşınca zikirden beklenen sonuç alınır." (Abdullah Hâni, 1976: 44) demelerinin sebebi, daha evvelki tekli adetlerde zikirden beklenen sonuca ulaşmaya engel değildir. Nitekim, on beş, on yedi, on dokuz adede ulaşan sâliklerde de bazen beklenen sonuç alınmıştır (Trabzonî, 158/10: vr. 171b; Ali Sâfî, 1256: 41). Eğer sonuç alınamazsa tekrar başa dönülür (Tokâdî, İrşâdu’sSâlikîn, 772: vr. 40a; Uludağ, 1991: 526).

Burada dikkat edilecek husus şudur: Eğer sâlik, tekli durmayı yirmi bir adede çıkardığı halde beklenen kalbi gelişme ve nurlanma elde edilememişse, o zaman sâlik zikrin 
edeplerinde kusur etmiş demektir. Yoksa bu noktaya gelen sâlikin zikrinden beklenen sonucu alması gerekmektedir. Bu durumda salik tekrar başa döndürülür ve iki nefes arasında üçer adetten başlamak üzere, haps-i nefes yoluyla tevhîd kelimesini zikre yeniden başlar ve devam eder.

Zikir sırasında sayıya riâyet etmek, aklı doğrulukta koruyup bir yerde toplamak, dikkati teksif etmektir. Mürîd verilen dersin adedine de vâkıf olmalıdır.

Şâh-1 Nakşbend Hazretleri zikirde sayıya dikkat ve riâyetin dağınık havâtırı toplayıp sildiğine işaret buyurmuşlar, "Vukûf-1 adedî" denilen usûlün ledün ilminin ilk mertebesi olduğunu söylemişlerdir (Ali Sâfî, 1256: 42).

İbadete taalluk eden hususların da zamanla kayıtlanması, bir takım kâidelere bağlanması, insanları disiplinli bir hayata sevkeder (Aktepe, 17).

Zikirde sayıya dikkatin önemi olmakla birlikte, asıl olan; sayının çokluğu ve azlığı değil, zikir sayısı az olsa bile, zikredilen zâta karşı kalp huzuruna sahip olmaktır. Kelime-i tevhîd'i zikrederken, nefy ve isbât anında, bedeni varlığın gidip, yerini ilâhi cezbelere terkedişi, zikrullahın gayesini teşkil eder.

Mürîd verilen dersin adedine de vakıf olmalıdır. Bahaeddin Nakşbend, kalbî zikirde adede riâyetin, sadece hatırda mevcut olan, bir takım şeylerin zihinlerden uzaklaşması ile zikrin sağlayacağı neticenin gerçekleşmesini temin olduğunu belirtmiştir. Zikirden beklenen esas gaye, zikredenin kalbinin Allah ile huzur bulmasını temindir (Aktepe, 18).

\section{BÂZ GEŞT}

Nefy-u isbât dediğimiz, bir tek nefeste, tefekkürî olarak yirmi bir adet "lâ ilâhe illallah" zikrinin çekilmesinden sonra, zikreden dervişin soluğunu bırakırken, zikrettiği şeyin manası üzerinde tefekküre dalması ve "Illâhi ente maksûdî ve ridâke matlûbî̀" diyerek tefekkürde derinleşmesi hadisesine "Bâzgeşt" denilir. Nakşî ıstılahındandır (Tokâdî, 772: vr. 39b; Tokâdî, 832: vr. 15a; Tokâdî, 1018: vr. 11b-12a; Semerkandî, 1273: 13; Cebecioğlu, 2005: 92).

Tarîkat edeplerinden üçüncüsü "Bâzgeşt”tir. Bunun anlamı şudur; Sâlik, nefesini tutarak ve tek adet üzerinde durarak zikrederken "İlâhi ente maksûdî ve ridâke matlûbî" cümlesinin anlamını düşünmekten ibarettir. "Allah'ım maksadım sensin; isteğim, sana kavuşmaktır”. Bu cümleyi düşünmenin faydası, iki nefes arasındaki durakta kalbe uygunsuz şey getirmemeyi temin etmektir. 
Burada asıl amaç, nefy-u isbâtın manasını te'kîd edip, tevhîd sırrının kalpte gerçek manada yerleşmesini gerçekleştirebilmektir. Böylece Allah ile arada perde olan bütün gaye ve arzular nefyedilerek kalbî itmi’nan hâsıl olur. Diğer taraftan zikir gibi manevi bir temrin ile mertebeler aşmak, kerâmetlere nâil olmak gibi gözle görülebilecek muhtemel vesveselerde tamamen reddedilip, asıl gayenin Allah rızâsını kazanmak olduğu düşüncesi gönüle bir kez daha nakşedilmiş olur (Topbaş, 2006: 237).

Zikrullah esnasında sâlik, kendiliğinden hatıra gelen iyi ve kötü her fikri kovmaya gayret etmelidir. Gönülde başka alâkalara yer kaldıkça, itminan teşekkül etmez ve yapılan zikir halis olmaz. Başlangıçta bu itmi'nâna erilemese de yine de zikrullâh'ı bırakmamak ve elde edilinceye kadar devam etmek gerekir (Aktepe, 17).

Bu uygulamada ki gaye, zikreden sûfînin Kelime-i Tevhîd'in manasını şuur altına yerleştirmesi ve onu hayatının bir parçası haline getirmesidir. Bu sır, bilinç altında öyle bir yer eder ki, sonunda o dervişin gözünde Allah'ın varlığından başka bütün varlıklar silinir, her yerde Hakk’1 görür ve bilir (Aktepe, 17-18).

Nakşbendîlikte en önemli esaslardan birisi budur. Yani, zikrettiği şey üzerinde tefekküre dalmak, zikrettiğinin manasını düşünmekle, zâkirin Allah-u Teâlâ'ya kavuşmasıdır (Aktepe, 18).

Sonuç olarak, zikri kuvvetlendirir, kalp üzerindeki tesirini arttırır. Bu cümleyi düşünmenin bir faydası da maksadın Yüce Allah olduğunu düşünerek O’na olan aşk ve muhabbeti arttırmaktır. Diğer bir faydası da, sâlikin zikir sırasında ihlâsını arttırmasıdır. Bu cümlenin iki nefes arasında düşünülmesi, orada olabilecek gafleti önler. Arasına gaflet giren zikir, saliki, fenâ'ya (Allah'ta yok olmaya) götürmez. Sâlik, zikri ile fenâ mertebesine ulaşamayınca zikirden beklenen de elde edilmemiş olur. Bunun içindir ki, bu cümlenin iki nefes arasında düşünülmesi salik için çok önemlidir.

\section{HÛŞ DER DEM}

Farsça, her an uyanık olmak demektir (Tokâdî, 772: vr. 38b; Tokâdî, 1018: 29; Mustakim-zâde, 625: vr. 55a; Ali Sâfî, 1256: 33) Nakşî ıstılahıdır. Sûfîlere göre, her insanın soluğu "hâ" sesi şeklinde vücuda girip çıkar. Bu "Hâ-yı Hüviyet"e işarettir. Bu bakımdan insanoğlu istese de istemese de sürekli zikir çekmektedir. Ancak insanoğlu farkında olmadığından bu zikir sayılmaz (Cebecioğlu, 2005: 286).

Tarîkat edeplerinden dördüncüsü olan kelime "Hûş der dem"dir. Bu kelime, sâlikin sürekli olarak giren ve çıkan nefeslerini kontrol altında tutmasıdır. Giren ve çıkan nefeslerini 
kontrolü altında tutan salik, nefeslerini gaflet üzere alıp vermekten korur. Bu ise çok önemli bir husustur. Tarîkatta bunun yeri çok önemlidir ve sâlik için yüce bir mertebedir.

Her alıp verilen nefeste mânen uyanık bulunma halindeki ölçüyü Mevlânâ Sa'deddin Kaşgârî; "Bir nefesten diğer bir nefese geçerken bile asla gaflete düşmemek ve daima Allah ile huzurda olmak” diye tarif eder (Topbaş, 2006: 235).

Nefesi kontrol altında tutmak huzur verir, huzur ise tarîkatın büyük bir rüknüdür. Nefeslerini kontrol altında tutmayan kimse onları boşa verir. Böyle bir kimsenin nefsine gücü yetmez. Nefsine gücü yetmeyen kimse bir gün sapıklığa düşer ve helâk olur. Nitekim Şeyh Şehâbettin Hazretlerinin şu sözü, bu sırrı biraz daha açıklar. Şeyh der ki:

"Kim alıp vermekte olduğu nefeslerine hâkim değilse, nefsine de hâkim değildir. Nefsine hâkim olamayan kimse ise mahvolmaya mahkumdur." (Topbaş, 2006: 236).

Bütün nefesler, vahdâniyyet menba-1, ma'rifetullah madeni ve bütün feyizlerin yeri olan kalp üzerinden alınıp verilir. Bu bakımdan alınıp verilmekte olan nefeslerin kontrol altında tutulması çok önemlidir. Bunun içindir ki, nefesler hayatın kaynağı ve dayanağıdır. Aldığı ve verdiği nefesten haberi olan ve onu kontrol altında tutan kimse, Yüce Allah'ın sırlarından bir sırra vakıf olur ve öyle olunca da o nefes "Nefes-i Rahmân” olur ki "Ben, Yemen tarafindan Rahmân'ın nefesini alıyorum." (Kenzu'l-Ummal, 16/33951) hadîs-i şerîfi bu konuya işaret etmektedir. Çünkü Allah Resûlü Efendimiz'in Yemen tarafindan almış olduğu rahmâni nefes Üveys el-Karânî (v. 657) idi.

Alınan her nefeste, Yüce Allah'ın birlik kokusu vardır. Kim nefesini yad ve yaramazlık karıştırmaktan sâfiyet üzere alırsa, muhakkak surette vahdâniyyet (birlik) kokusunu alır. Kulun ibadetinin efdali, nefes ile yaptığı ibadet olduğu gibi, kabahatinin çirkini de nefes ile yaptığıdır. Yani nefes alıp verirken ki ibadet hali ne kadar güzelse, aynı zamanda işlediği kabahati de o derece çirkindir. Bir nefeste yaptığı ibadetle kişi en yüksek makama erişebileceği gibi, yine bir nefeste yapacağı günahla da en aşağı dereceye iner. Bunun içindir ki, Allah'ın velî kulları nefesleri kontrol altında bulundurmayı en büyük ibadetlerden saymışlardır.

Burada konuyla ilgili olarak, Cüneyd-i Bağdâdî (v. 911) Hazretlerinin şu sözlerini zikretmek oldukça faydalı olacaktır. Bağdâdî der ki:

"Nefeslerin en güzeli, geçmiş günahlara pişmanlık duyularak alınıp verilen nefestir. Hiçbir ibadetin fazîleti buna denk olamaz. İmanla alınıp verilen nefesler, ibadetin en üstünü, 
küfürle alınıp verilen nefesler ise en çirkinidir." (Kuşeyrî, 1997: 177) sözleriyle konunun ehemmiyetine ve manayı kuvvetlendirmeye katkıda bulunmuştur.

Nefes, Tarîkat-1 Âliyye'de terakkî edip yükselmenin temelidir. Nefeslerin vücûda gafletle girip gafletle çıkmamasına azamî gayret sarfetmek gerekmektedir. Nefesleri gafletten korumak, kalbi huzura kavuşturur. Bunun içindir ki bütün nefesleri Allah ile alıp vererek kalpteki huzuru muhafaza etmek gerekir (Aktepe, 18).

Sûfîlere göre her insanın soluğu "ha" sesi şeklinde vücuda girer, çıkar. Bu "ha" Hüviyyete, yani Allah'ın zatına işarettir. Buna göre insanoğlu her nefeste istese de istemese de zikir çekmektedir. Fakat bu hal, işin farkında olmayan için zikir sayılmaz. Zikir hali her an Allah’ı düşünen kişi için mevcuttur (Aktepe, Aynı yer).

Sâlik, zikrettiğinin manasını düşünürse, Mezkûr'un tecellisine mazhar olur. $\mathrm{Bu}$ da ancak nefesleri alıp verirken gafletten kurtulmakla olur. Nefeslerine muhafaza eden ve gafletten kurtulan kimse huzura erer, her an Allah-u Teâlâ ile beraberdir ve O'nun tecellilerini görür (Aktepe, 19).

"Nefeslerine mâlik olamayan, nefsine de mâlik olamaz. Nefsine mâlik olamayan ise, helâk olmaya mahkûmdur" denilmiştir.

\section{NİGÂH DÂŞT}

Farsça, gözü korumak manasına gelmektedir. akılda gezip dolaşan düşünceler (havatır)'i kontrol altında tutup, Allah'tan gayrı her şeyi (mâsivâ)'yı terk etmek, kalbinden atmaktır (Cebecioğlu, 2005: 482).

Tarîkat edeplerinden beşincisi olan kelime "Nigâh Daşt”tır. Bu kelime, Yüce Allah’tan başka şeylere karşı nefsi korumaktan kinâyedir (Tokâdî, 772: vr. 39b; Tokâdî, 1018: vr. 12a). Bilindiği gibi Yüce Allah kalbi, Zâtının Cemâline ayna kılmış, kullarını da isim ve sıfatlarının mazharı olacak şekilde yaratmış, Allah’tan başka şeylerle kalbi doldurmayı da isim ve sıfatların kalpte görülmesine perde eylemiştir. Kim kalbine ondan başka şeylerin dolmasına engel olmazsa, O’nun Zâtının güzelliklerini, isim ve sıfatlarının nurlarını seyredemez.

Asıl amaç, nefsâni ve şeytânî havâtırdan korunmaktır. Gözü uygunsuz şeylere bakmaktan, aklı kötü düşüncelere dalmaktan muhafaza etmek ve Hakk'ın tecelligâhı olan kalbi daima kontrol altında tutarak, mâsivânın orayı istila etmesine mani olmaktır (Topbaş, 2006: 237). 
Sâlikin önemli görevlerinden birisi, kalbi, havâtır denilen yâd ve yaramazlıklardan korumaktır. Kalbini, bir saatin yarısı, hatta dörtte biri kadar zaman süresince yâd ve yaramazlıklardan koruyabilen bir kimse Yüce Allah'ın Zâtının güzelliğini, sıfatlarının nurlarını seyredebilir. Ne var ki, kalbi bu kadar zaman bile yâd ve yaramazlıklardan koruyabilmek çok zordur. Bunu kazanmak için çok mücâhede etmek gerekir. Bunun içindir ki, kalbi havâtır denilen Yüce Allah’tan başka şeylerden korumak veya koruyabilecek yere gelmek yüce bir makamdır (Semerkandî, 1273: 13).

Kalbe perde olan hâtırâlar altı kısımdır:

1) Hevâcis cinsinden olan hâtırâlar; bunlar, nefis yoluyla kalbe giren şeylerdir.

2) Vesvese cinsinden olan hâtırâlar; bunlar, şeytan tarafından kalbe sokulan onun istediği şeytanlıklardır.

3) İlhamlar cinsinden olan hâtırâlar; bunlar, melek tarafından kalbe giren şeylerdir.

4) Vâridât cinsinden olan hâtırâlar; bunlar, Allah tarafindan kalbe girerler.

5) Eşyanın görünümleri şeklinde kalbe giren hâtırâlardır ki; bunlar, hisler yoluyla kalbe girerler.

6) Mâ'kulât cinsinden olan hâtırâlar; bunlar, akıl yoluyla kalbe giren hâtırâlardır.

Bu hâtırâların tamamı, sülûka henüz başlamış kimse için birer perdedir. Sülûka yeni başlayan bir sâlik bu perdelerin tamamından kendini korumalıdır. Yani kalbine bunların girmesine engel olmaya gayret göstermelidir. Kalbin nurlanması ve tecellilere ayna olması böylece mümkün olmaktadır.

Müşâhede makamına erişen sâlik için hâtırâlar, müşâhedesine engel değildir. O makamda, hâtırâlarla bile Yüce Allah'ın güzelliklerini, isim ve sıfatlarının nurlarını sâlik seyreder. Hem o derece seyreder ki, sanki zâhirdeki bir şeyi görüp seyrediyor gibi olur.

Kalbi hâtırâlardan korumanın başlıca yolu, "Havâss-1 Hamse" olarak bilinen duyu organlarını dış alemden ilgisiz kılmaktır. Kalbe dolan hâtırâların çoğu bilhassa göz ve kulak yoluyla gelir. Aklı düşünmekten alıkoymakta büyük önem taşır. Mürşidin emir ve tavsiyelerinin içinde kalmak, hatıralardan kurtulmanın en akıllı yoludur. Bu arada tevhîd kelimesini zikre devam ederek kalbi daima tecellîlere açık bulundurmak ve bol bol istiğfarda bulunmak, mümkün olduğunca insanlardan uzak durmak, az konuşmak hâtırâlardan kurtulmanın esaslarını teşkil ederler (Gündüz, 1984: 235). 
Akılda gezip dolaşan düşünceleri kontrol altında tutup, Allah’tan gayrı her şeyi kalpten atmaktır. Hakk'ın tecelligâhı olan kalp evine, O'nun yüce zâtına yabancı şeylerin, uygunsuz hâtırâların girmesini engellemektir.

Ayrıca zâkirin, nefy ve ispât manasını düşünerek kalbini koruması gerektiğini ifade eder. Nefy ve ispâtın manası düşünülmeden yapılan zikirlerde kalbe havâtır gireceğinden, zikrin neticesine ulaşılmamış olur. Zikrin neticesi ise kalbin Allah ile huzur bulmasıdır (Aktepe, 19).

Sâlikin kalbini gözetim altında tutması, dünya işlerini kalbe sokmamaya çalışması da hatıralardan kurtulmak için takip edilecek yollar arasında önemli bir yere sahiptir.

\section{VUKÛF-I KALBî}

Arapça, kalbe dikkat etmek demektir. Buna "Gönül'e varıp, gönüllü beklemek" şeklinde tanım getirilir. Kalbin, Allah’tan gayrı her şeyden sıyrılıp, Allah tefekküründe sürekliliği koruyarak O’nun üzerine yoğunlaşması ve sadece Allah'1 düşünmesidir (Tokâdî, 772: vr. 40a-40b; Cebecioğlu,2005: 703).

Zikrin edeplerinden altıncısı olan kelime, "Vukûf-1 Kalb̂̂”dir. Bu da kalp kozalağını göz önüne getirip, basîret gözü ile onun gerçeğine bakıp durmaktır.

Sâlik, bütün varlığıyla gögüs kafesinin sol tarafında bulunan kalp kozalağının içindeki kalp hakîkati üzerinde dikkat kesilip bu dikkatine süreklilik kazandırmalıdır. Bu haline, kendisinde başkalaşma, bir cezbe veya sülûkta meydana gelen hallerden bir hal meydana gelinceye kadar devam etmelidir (Trabzonî, 158/10: vr. 172a). Bundan sonra, meydana gelecek hale göre hareket edilir. Sonra yine vukûf-i kalbî’ye devam edilir. Meydana gelecek yeni hallenmeye göre harekete devam edilir. Sâlik, vukûf-i kalbî'ye, burada hallenme yerleşinceye kadar devam eder. İstediği an kalp kozalağı içindeki cevheri yakalamayı kesinleştirdiği zaman bu yerde hallenmiş ve istediğine erişmiş demektir.

Kalbin daima zikr-i ilâhiyle meşgul olmasının bir neticesi olarak, ihsân duygusu dâimî bir şuur halini alır. Burada sâlik her firsatta kalbini yoklamalı, onun ne halde olduğuna bakmalıdır. Zira zikirde asıl matlûb, kalbin zikredilenden haberdar olmasıdır. Zikir, ağızdan kalbe inmeyen kuru lafizların tekrarından ibaret değildir. $\mathrm{Bu}$ sebeple zikir esnasında murâkabe halinde olmalı, bütün dikkati zikredilene teksîf etmeye çalışmalıdır. Sâdât-1 Kirâm hazerâtı, vukûf-1 kalbînin, yani dikkati kalbe yöneltmenin zikirde şart olduğunu söylerler. Zikrin gerçek muhtevasını tadabilmek için, bütün varlığın ve hususen kalbinde Allah'a yöneltilmesi îcâb eder. Bu meyanda Cenab-1 Hakk şöyle buyurur; 
“Rabbinin ismini zikret ve bütün varlığınla O’na yönel” (el-Müzzemmil, 73/ 8).

Nakşbendî tarîkatında sâlikler, sülûkun diğer usûl ve edepleriyle meşgul olmadıkları için bir kayba uğramazlarsa da mürşîller, sâliklerine sürekli olarak vukûf-1 kalbî’yi öğretip onunla meşgul ederler. Daha sonrada diğer şeylerle meşgul edip terbiye eder ve Hakk (c.c.)'a kavuşmalarına vesile olurlar. Vukûf-1 kalbî için aynı zamanda "Aslın Aslı” tabiri kullanılmıştır.

Müridin her türlü bağdan, evhamdan, şek ve şüpheden; bilinen, düşünülen, hatır ve hayalden geçirilen her türlü fikir, hayal ve histen sıyrılıp, sâdık bir teveccüh ile kalbine yönelmesine, her an gönlünü Allah'a karşı uyanık tutmasına denir (Aktepe, 19).

Nitekim her yerde hazır olan Allah-u Teâlâ'ya nasıl ki Kâbe-i Muazzama'ya yönelerek el açılıyorsa; zikir sırasında da kalbe yönelmek, oraya ilâhi tecellilerin dolmasına zemin hazırlar (Aktepe, 19-20).

Allah-u Teâlâ insanın kalbine hakîkatini yazmış, sonra da o hakîkati fenâ sıfatlarla örtmüştür. Eğer bir kimse kötü sıfatlarını temizlerse, kalbine teveccüh ettiğinde kendi hakîkatim görür. Bundan maksat, Hakk'tan başka sevgilerin kalbe girmemesidir. Aldığı ve verdiği nefesleri düşünerek daima Hakk ile olması, gelen bütün kötülük ve hatıralardan gönlünü muhafaza etmesi lazımdır (Aktepe, 20).

Eğer sâlik buna muvaffak olursa kalbinde hakîkat zuhûr eder. Sâlik kalbine teveccüh hususunda 1srar etse, kendi hakîkati ona aşikâr olur. Böylece Hakk'ın birçok esrarı tecelli eder. "Men arefe" nin sırrı burada çözülmeye başlar (Aktepe, Aynı yer).

Vukûf-i kalbi, Tarîkat-1 Nakşbendiyye'nin Râbıtâ, Zikir, Murâkabe, Hıfz-1 nisbet ve Şeyh ile sohbet gibi altı rükünden birisidir.

\section{YÂD DÂŞT}

Farsça, hatırda tutmak, zihinde tutmak manalarına gelen bir tabirdir. Nakşî 1stılahındandır. Allah'ın sürekli görmekte ve bilmekte olduğunu bilmek ve bunun bilincinde olmaktır (Cebecioğlu, 2005: 706).

Tarîkat edeplerinden yedincisi "Yâd Dâşt”tır. Bu kelime, Yüce Allah'ın varlık ve birliğini her durumda ve her işte sürekli murâkabe etmekten ibarettir (Semerkandî, 1273: 13; Gündüz, 1984: 235).

Cenâb-1 Mevlâ âyet-i kerîme de şöyle buyurur; 
"Andolsun, insanı biz yarattık ve nefsinin kendisine fisıldadıklarını da biliriz. Biz ona şah damarından daha yakınız." (el-Kâf, 50/16).

Bu sebeple ihsân duygusunu, yani Cenâb-1 Hakk'1n, kulunu her an görmekte ve her halini bilmekte olduğu şuurunu hiçbir zaman kaybetmemek icâb eder. Hakîkaten bu duygu, günahlara karşı sağlam bir zırh gibidir. Zira bir insan, kendini ilahi huzurda bilmekteyken ve ve kalbi Allah ile beraberken nasıl günah işleyebilir? (Topbaş, 2006: 238).

Yâd Dâşt, yani murâkabe nasıl yapılmalıdır? Sorusuna gelince; bu hususu şöyle anlatmak gerekir:

Sâlik, bütün hatıraları kalbinden çıkarıp, hareket ve hisse dayalı işlerini de tatil ederek bütün varlıkları asıllarındaki yokluklarında yok kabul eder. Yüce Allah'ın var ve bir olan Zâtını, varlık âlemini kuşatmış olarak düşünür. Bu kuşatmanın, madde, ölçü, renk, şekil, yön ve mekan gibi şeylerden münezzeh olduğunu, O’nun Zâtına mahsus ilahi bir nur olarak bütün eşyada seyreder. Buna her zaman ve önemle devam eder. Her şeyde O’nu murâkabe etmeye ve O'nu seyretmeye meleke hasıl oluncaya kadar murâkabeyi terk etmez. Nitekim bir hadîs-i şerif’te "Ben Rabb’imi nûrânî gördüm." (Buhâri, Enbiyâ, I, Müslim, Kader, I) buyurulmuştur.

Hadîs-i şerif'te anlatılan görmeden kasıt, baş gözü ile herhangi bir şeyi görmek gibi değildir. Buradaki görme müşahede anlamında bir görmedir. İmamı rabbâni’ye göre Yâd-dâşt sâlik ile Allah arasındaki ilişkinin özü denebilecek bir bağdır (Sirhindî, 194: I, 21, 206, 290).

Murâkabe sırasında sâlikin kalbine hatıralar dolarsa, gözünü bir şey üzerine yoğunlaştırıp hatıralar dağılıncaya kadar ondan ayırmamalı, yahut da gönlüyle Yüce Allah'ın Zatının varlık ve birliğini düşünmeli ve buna devam etmelidir. Kalbe tecelliler dolup hatıralar dağılıncaya kadar bu hali sürdürmelidir.

Yâd dâşt " Nakşbendîlik'te, Allah'ı hatırlama halinin daimi olması, nefesi hapsederek nefy ve ispât zikrini yapan sâlikin Allah'ın huzurunda olma halini kalbinde muhafaza edebilmesi, kalbi, Zâtî tecellilerin şuhûdu üzere korunmasıdır (Tokâdî, 772: vr. 39b; Semerkandî, 1273: 13). Buna murâkabe, müşâhede, gaybetsiz huzur, ihsân da denilir (Aktepe, 20).

Yâd dâşt, nigâh dâşt'ın manasını derinliğine anlamak, yaşamaktır. Zikirden hasıl olan huzur, murâkabe, sohbet, râbitâ, yâd dâşt terimiyle aynı manaya gelmektedir. Fakat keyfiyyet yönünden birbirlerinden ayrıdırlar ki, bunu da ancak işin ehli bilebilir (Aktepe, 21-22). 
Yâd dâş̧; Yâd kerd, Bâz geşt ve Nigâh dâş̧t kâidelerinin gayesidir. Bir başka ifadeyle Murâkabe mertebesine ulaştıktan sonra sâlikin lisanla belli sayıda Kelime-i tevhîd'i zikretmesidir. $\mathrm{Bu}$ yoldan kalbin pası silineceğinden şuhûd mertebesine ulaşılır, kâinattaki sınırsız çoklukta vahdâniyyet-i ilâhi müşâhede edilir (Aktepe, 22).

Bu konu ile ilgili bu nüktede çok önemlidir: "Kalpler, bir takım hatıraların doluşmasıyla tehlikeye girdiği zaman onu korumaya almak ve üzerinde murâkabe etmek en güzel ameldir.” Sözü konuyu daha da güzel anlamamıza yardımcı olmaktadır.

\section{NAZAR BER KADEM}

Arapça ve Farsça kelimelerden mürekkeb olan bu ifade, ayağa bakmak anlamına gelir. Nakşî 1stılahıdır. Sülûk gören kişinin, nerede olursa olsun, zihni konsantrasyonunu dağıtmamak için, devamlı ayağının ucuna, yürüyeceği yere bakmasıdır. Bu kendini beğenme hastalığından kurtulmaya vesile olarak görünür (Cebecioğlu, 2005: 467).

Tarîkat edeplerinden sekizincisi, "Nazar ber Kadem”dir. Sâlikin, yürürken sağa sola bakmayıp ayaklarının ucuna bakarak yürümesi bu kelimeyi ifade eder (Ali Sâfî, 1256: 34). Sülûka başlama sıralarında olan bu sâlik, yürürken sağa sola baktıkça gördükleri gönlüne dolar. Bu durumdan kurtulmak için hep öne ve ayak uçlarına bakmak, yegâne yol ve çaredir (Mustakim-zâde, 625: vr. 55a; Gündüz, 1984: 233). Hele sâlikin bakmas1; kendisine haram olan insanlara bakarak, onların ilgisiyle kalbini doldurması ise büsbütün felakettir. $\mathrm{Bu}$ durumdu sülûku bâtıl olur. Hak ve hakîkatle ilgisi kesilir. Bu hususta söylenen şu sözde çok kıymetlidir: "Sağa sola bakmaya devam edenin, zarar ve ziyanı devam eder."

Bu usûl, Hz. Peygamber'in yürüyüş tarzını tatbikten ibarettir. Resûlullah Efendimiz, yürürken gerekmedikçe etrafına bakınmaz, umumiyetle ayaklarının ucuna bakarak, sanki yokuştan iniyormuş gibi seri ve vakarlı yürürlerdi, yani bu prensip, Allah Resûlü’nün örnek ahlakından muktebestir (Topbaş, 2006: 235).

Göz nereye bakarsa gönülde oraya akar. Salikin kalbi mâsivâya takılınca vesveseler başlar. Şayet gafillerle ihtilât ederse, onların katı kalplerinin kasveti, kötü huyları ve bozuk fikirleri kalbine akseder. Bu ise son derece tehlikelidir (Topbaş, 2006: Aynı yer).

Göz kalbin penceresidir. Gözün gördükleri kalbi meşgul eder, nazargâh-1 ilâhî olan gönülü havâtır kaplar (Aktepe, 21).

Bunun içindir ki bir sâlik yolda ve izde, kalabalıkta, tenhada bakışlarını ayak ucunda toplayacak ki; hem harama bakmaktan, hem de gözünü başıboşluktan, istediği yere 
bakmaktan korumuş olsun. Aynı zamanda havâtıra düşmekten de kurtulmuş olur. Gönlünü toparlaması kolaylaşır (Aktepe, 20).

Bu usûl Sünnet-i seniye'ye de uygun düşmektedir. Zira Resûlü Ekrem Efendimiz yolda yürürlerken sağa sola bakmazlardı (Aktepe, 21).

Bir de var ki, insanın her yaratılan şeyde Allah-u Teâlâ'nın eserlerini görmeye çalışması gerekir. Bu tefekkür sayesinde iman tekâmül eder. Bu da bâtınîdir (Aktepe, Aynı yer).

$\mathrm{Bu}$ gibi kimseler Hazret-i Allah ile baktığı için, her zerrede O'nun eserini, asarını seyreder. Bu, Hakk'tan Hakk'ın yarattıklarına seyirdir (Aktepe, 22).

Meselâ bir yaprağı ele alır, O'nun asarını onda seyreder, azamet-i ilâhî karşısında bir zerrenin idrakinden âciz olduğunu itiraf eder (Aktepe, 23).

Orta halli ve sülûkunu tamamlama noktasına gelen bir salik bile, yürüyüşü sırasında sağa sola bakıp gördüklerine takılırsa kalp huzuru ve gönül saltanatı yıkılıp gider. Kaçırılan huzuru ve boşalan kalbi bir daha doldurup düzeltmek çok zor olur. Hangi seviyede bulunursa bulunsun, salik yolda yürürken ayağının ucuna bakarak yürümelidir. Bunun bir anlamı da salik, her şeyden el çekip, muhabbetini Yüce Allah’a ve O’na vuslata yöneltmeli, gözünü ve gönlünü O'ndan başkasından ayırmalı ve kalbini O'nun tecellilerine açık ve temiz bulundurmalıdır. Eğer namaz kılan kişi, namazda başka yere bakarsa, ihsan mertebesinden uzaklaşmış olur (Tokâdî, 772: vr. 38b-39a; Tokâdî, 1018: 30; Tokâdî, 832: vr. 13a; Tokâdî, Risâle fi Hakki Sülûk, 1018: vr. 11b; Mustakim-zâde, 625: 55b).

\section{HALVET DER ENCÜMEN}

Farsça, toplum içinde yalnızlık manasına gelir. Nakşi bir 1stılah olarak, toplulukta Allah ile yalnız kalabilme sanatını ifade eder (Cebecioğlu, 2005: 259).

Tarîkat edeplerinden dokuzuncusu "Halvet der Encümen"dir. Bu, görünüşte insanlarla beraber olup, kalben Yüce Allah ile beraber olmak demektir (Mustakim-zâde, 625: vr. 56a; Semerkandî, 1273: 12; Arap-zâde, 6542/2: vr. 14b). Halvet der Encümen, müntehî olan sâliklere mahsus bir haldir. Yolun henüz başında bulunan salikler, gördükleri ve beraber oldukları kimselerin kolayca tesirinde kalabilirler. Bu da bağlılıklarını ve kalp safiyetlerini zedeler.

Yolu henüz başında bulunan salik mümkün olduğunca insanlardan uzak kalmaya ve Yüce Allah ile yakınlık kazanmaya gayret etmelidir. Ancak, salikin yakın olduğu kişiler, 
Hakk'a yakınlığına engel değillerse o zaman onlarla ünsiyette bir zarar ve sakınca olmaz. İnsanlarla ünsiyet, Hakk ile halvet olmaya da engel olmamalıdır.

Yani salik zahiren insanlarla ihtilat halindeyken ve günlük işleriyle meşgulken bile, bâtınen Hakk Teâlâ ile beraber olma dirayetine erişmelidir. $\mathrm{Bu}$ sayede etrafına hissettirmeksizin Rabbiyle beraberliğini sürdürmüş ve aynı zamanda beşerî hayatın îcaplarını da aksatmamış olur (Topbaş, 2006: 236).

Ashâb-1 kirâm, Allah'ın Resulü'nün sünneti üzere yürüdüler. Onların hali, görünüşte halk ile, gönülden Hakk ile beraber olmaktı. Çünkü herkss bir işle meşgul olurken Rabb3ani feyizler uyanık kalplere iner (Tokâdî, 772: vr. 39a; Tokâdî, 1018: 31; Tokâdî, 832: vr. 12b; Tokâdî, 1018: vr. 11b).

Cenâb-1 Mevlâ Kur'ân-1 Kerim'de bu kalbî dirâyete sahip kullarının şan ve şereflerini şöyle tavsif buyurur;

“Onlar, ne ticaretin ne de alışverişin kendilerini Allah'ı anmaktan, namaz kılmaktan

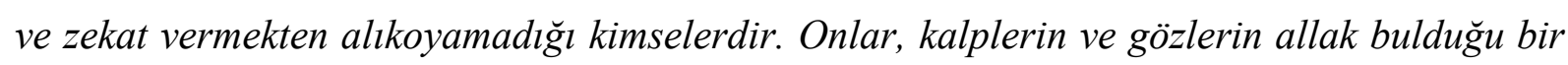
günden korkarlar.” (En-Nûr, 24/37; Tokâdî, 772: vr. 39b; Tokâdî, 1018: vr. 12a).

Diğer tarîkatlarda görüldüğü üzere, zahirde halvet, batında halveti kazanmak içindir. Halvet için her zaman insanlardan uzak kalmak makbul değildir. Hatta bid'at'ta denilebilir. Çünkü Allah'ın Resulü peygamberlik şerefi ile şereflendikten sonra hiçbir zaman insanlardan uzak kalıp, kendi kendine halvete çekilmemişlerdir.

Hâcegân Hazretleri ve Nakşbendî mürşidleri de, sünnet üzere yürüyüp halk ile birlik olmayı, Hakk ile de halvet olmayı benimsemişlerdir. Yani görünüşte halk ile oldular, gerçekten ve gönülden Hakk'tan ayrılmadılar. Yerinde ve sırasında Hakk ile halveti, halk ile beraber olmaya tercih ettiler. Halk ile beraberlik, hiçbir zaman Hakk ile beraberliğe engel olmamalidır.

Bu kâide, sûfinin bir köşeye çekilmeyip halk arasına karışmasını, ancak bedenen halk arasında iken, kalben onlardan ayrı, yalnız ve sadece Allah'la olmasını gerektirir. Zâhirde halk ile, batında Hakk ile olmak; bedenen halk ile, kalben Hakk ile olmaktır. Bunu tasavvuf literatüründe "El kârda, gönül yarda" sözüyle de açılamak mümkündür (Aktepe, 22).

Halvet der Encümen'in bir tezahürü, edebi muhafaza etmektir. Sûfiler kime ne muamele etseler, hak ölçülere, İlâhi emirlere uygun davranırlar. Onların bütün işleri ve davranışları kendilerinin Allah adamı olduklarını ortaya koyar (Aktepe, Aynı yer). 
Bir diğer tezahürü ise, Sûfinin dünyevi bir işle meşgul olarak sıradan yaşaması ve bu sayede manevi halini halktan gizlemesidir ki bu melâmet düşüncesinden gelmektedir. Kalbinin içinde ki aşk1, zikri, ilim ve marifetleri gizler. Halktan birisi gibi görünür. Halini yansıtacak özel bir kıyafet seçmez. İnsanlar tarafından bilinmek ve övülmek istemez. Allah-u Teâlâ tarafından kendisine nasîb edilen manevi ilim, muhabbet, keşif ve kerâmet gibi özel hallerinin bilinmesinden utanır (Aktepe, 23).

Bu konuda Nakşbendi tarîkatı kurucusu, Şeyh Muhammed Bahâüddin hazretleri şöyle buyurmuşlardır: “Bizim yolumuz sohbet yoludur. Hayır ve bereket de topluluktadır.” (Büyük İslam ve Tasavvuf Önderleri, 1983: 86-87).

Burada şu hususu da özellikle akıldan çıkarmamak gerekir. Halkın sohbeti, Hakk’ın halvetine engel olduğu zaman halkla sohbet terk edilir.

\section{SEFER DER VATAN}

Arapça ve Farsça'dan oluşan bir sözcüktür. Vatanda yolculuk yapmak demektir. Salikin, fena huylardan iyi huylara yönelmesi; beşeri sıfatlardan, melekî sıfatlara ulaşması demektir (Arap-zâde, 6542/2: vr. 14b; Müstakim-zâde, 625: vr. 55b). Maddi yolculuk ile bir kimsenin kötü huylarını bırakması mümkün değildir (Cebecioğlu, 2005: 550).

Tarîkat edeplerinden onuncusu, "Sefer der vatan”dır. Salikin, masiva'yı terk edip, Yüce Allah tarafına yürümeden önce, ya salikin kötü huylarının iyi huylara dönüşmesi, yahut Mülk aleminden Melekût alemine, ya Melekût aleminden Ceberût alemine, ya Ceberût aleminden Lâhut alemine yükselmesi, yahut salikin, ilmel-yakînden aynel-yakîn'e ve aynelyakîn'den Hakkel-yakîn'e geçmesinden ibarettir. Sâlik, yukarıda sıralanan mertebelerde manevi yolculuğunu tamamlamadan Yüce Allah'a yakınlık elde edemez.

Çünkü Yüce Allah'a yaklaşmanın yolu, manevi olan bu yoldur. Manevi yolculukta elbette ki manevi zemin üzerinde olur. Salikin, zahirdeki yolculuğu, batındaki yolculuğunu kazanmak içindir. Zahirdeki yolculuk, batındaki yolculuğu kazandırmazsa salik için abes bir yolculuk olur ve boşuna zahmetten başka bir şey elde edilmiş olmaz. Sonucu maneviyata çıkmayan her yolculuk, günaha ve ibadetleri terk etmeye çıkar. Bazı hakikat erbabı; sonucu maneviyata çıkmayan yolda yürümenin salik için haram olduğunu söylemişlerdir. Çünkü helale çıkmayan yol, harama çıkar. Bundan dolayıdır ki Hâcegân Hazretleri zahir yolculuğu önemsemiş ve "Salikin seferi (gönül) vatanındadır." buyurmuşlardır. "Vatan sevgisi imandandır." (el-Aclûnî, 1352: I, 345) Sözü de bu anlamda değerlendirilir (Tokâdî, 772: vr. 39a; Tokâdî, 1018: 30-31; Tokâdî, 1018: vr. 11a; Ali Sâfî, 1256: 33-34). 
Bu konu ile ilgili Ebû Osman Mağribi şöyle buyurmuştur;

"Sâlik, hevâ ve hevesini terk edip Allah'a ibadet ve tâata dönmelidir. "Sefer der vatan" sözüyle kastedilen, bir memleketten diğer bir memlekete yolculuk etmek değil, insanın kendi iç aleminde Allah'a vuslatıdır. Sâlik, bir mürşid-i kâmil bulduğu zaman zâhirî yolculuğu bırakıp Bâtınî yolculuğa başlar.” (Topbaş, 2006: 236).

Seyr-u sülûkta bu düstûr ile sâlik, "Ben Rabbime gidiyorum" (es-Saffat, 37/99). İbrahim (a.s.) gibi, her adımda Rabbine gitmekte olduğunun idrâkine ulaşır.

Nakşî şeyhleri, bir mürşîd bulana kadar zahiri manada sefer yapılmasını tavsiye etmiş, irşad ediciyi bulduktan sonra onun terbiyesinde ikâmet edip batını sefere başlamanın önemini vurgulamışlardır (Aktepe, 23).

Salikin kötü huylardan iyi huylara, beşerî sıfatlardan melekî sıfatlara, halktan Hakk'a, mülk aleminden melekût alemine, ilme'l yakîn mertebesinden ayne'l yakîn mertebesine doğru sefer etmesi, ahlâkını değiştirmesi, ruhen güzelleşmesidir (Aktepe, 24).

\section{VUKÛF-I ZAMÂNî}

Arapça, zamanı korumak demektir. Sâlikin her an halinden haberdar olmasına denir. $\mathrm{Bu}$ şekilde sâlik, içinde bulunduğu halin şükrü mü, yoksa özrü mü gerektirdiğini bilir ve ona göre davranır (Cebecioğlu, 2005: 703).

Tarîkat edeplerinden on birincisini ve sonuncusunu ifade eden kelime; "Vukûf-1 Zamânî”dir. Bunun anlamı, bulunan hali bilmek ve geçmişin hesabını iyice yapmaktan ibarettir. Salik, zamana çok önem vermeli, ibadetlerini ve üzerine düşen her şeyi zamanı içerisinde yerine getirmeye gayret göstermelidir. Daha akşam vaktinde sabahını, sabah vaktinde de akşamını düşünmeli, geçen akşam ve sabahlarının ne işe yaradığının, boş geçip geçmediğinin muhasebesinde kusur etmemelidir (Tokâdî, 772: İrşâdu's-Sâlikîn, vr. 40a).

Geçen vakitlerinin iyi değerlendirilemediği sonucuna varırsa, hemen pişmanlık duyup eksiklerini tamamlamaya yönelmeli, iyi değerlendirildiğine inanırsa, Yüce Allah'a, kereminden dolayı şükretmeli ve sorumluluklarını yerine getirmeye devam etmelidir.

Sâlik, her an kendi halinden haberdar olmalı ve halinin şükür mü yoksa özür mü gerektirdiğini bilerek mûcibince amel etmelidir. Salik, her an ve halinin muhasebesini yaparak huzurda geçirdiği ânına ve hâline şükredip, gaflette tükettiği zamanlar için tevbekâr olmalıdır. Kabz halinde istiğfâra, bast halinde ise şükre devam etmelidir (Aktepe, 25). 
Vaktini boşa geçirdiğine kanaat getiren salik, henüz mübtedî (intisâb etmiş) bir kimse ise, daha çok boş geçirdiği vaktini günah işleyerek geçirmiş olabilir; bu durumda hemen tevbe ve istiğfar etmelidir. Vaktini boşa geçirdiğine kani olan salik, orta seviyede kimse ise, o da çoğunlukla vaktini gaflette geçirmiştir. $O$ da gaflette geçirdiği zamanı için yine tevbe ve istiğfar etmeli, bir daha gaflete düşmemek için kendi kendine söz vermeli, aklını kalbinden ayırmal1, her zaman Yüce Allah'ın kendisiyle beraberliğini gözünden uzak bulundurmamalıdır. Vaktinin boşa geçtiğini anlayan salik, manevi yolculuğunun sonuna yaklaşmış bir kimse ise, o kimse kalbini Yüce Allah'tan başka şeylerle doldurup perdelemiş demektir ki, bu durumda büyük bir kayba uğramıştır. Bu durumda bulunan müntehi salik, hemen toparlanıp tevbe ve istiğfar etmeli, gönlünde perde olan şeyi derhal çıkarıp atmalı, murakabeye dalarak eski halini bulmaya çalışmalıdır.

Bütün bunlardan anlaşılması gereken husus şudur: Sâlik, sülûkunun hangi aşamasında bulunursa bulunsun, zamanı iyi kollamalı, korumalı ve değerlendirmelidir. Hemen her seviyede zamanı boşa geçirme tehlikesi vardır. Salik, bunu aklından hiçbir zaman çıkarmamalıdır. Salik için zamanı kollamak, boşa geçen zamanı varsa hemen eksiklerini giderip tamamlamak kendisine vaciptir. $\mathrm{Bu}$ hususta salik“" Vaktine dikkat edip önem vermeyen kimsenin hayatı sıkıntıdan ibarettir." "Vaktinin önemini kavrayan rahat eder; onu kavrayamayan sıkıntıya düşer” (Kuşeyrî, 1997: 55; Aktepe, 27) sözlerini kendine düstûr edip, işin önemini daha iyi kavramalı ve bu konuda amaca ulaşmak elinden gelen bütün çabayı sarf etmelidir.

Mürid bütün gayreti ile boş vakit geçirmemeye çalışmalı, bütün zamanlarını iyi değerlendirmelidir. Huzurla geçirdiği zamana ve hâline şükretmeli. gafletle geçirdiği zamanlarına da tevbekâr olmalıdır. Bir başka ifade ile kabz halinde istiğfara, bast halinde şükre devam etmelidir (Aktepe, 27).

Vaktinin önemini kavrayamayan ve onu boşa harcayan kimsenin gecesini ibadetle, gündüzünü de oruçla geçirmesi gerekir. Verilen zikre devam edip, murakabe ehli kimselerden ayrılmamalıdır. Gönül gözü açık olanların, zamanları müşahede ile dolu olmalı, bu halini her geçen gün daha ilerilere götürmelidir. Bu durumda bulunan kimse kalbini ikilikten, gafletten ve özellikle kalbe Allah sevgisinden başka şeyler dolmasından çok sakınmalı ve kalbi bunlardan korumalıdır (Aktepe, 29).

Dili, çok konuşmaktan, hele hele faydasız ve yalan şeyler konuşmaktan mutlaka uzak tutmalı, gözü yasak olan şeylere bakmaktan, kulağı dinlenmesi yasak olan şeyleri dinlemekten 
mutlaka korumalı ve engellemelidir. Ayak, zararlı yerlere gitmemeli, her zaman faydalı yerlerde dolaşmalıdır. Az yemek, haram yememek, açlık ve susuzluğun faydasını bilip inanmak gerekir (Aktepe, 28).

Şeyh derki; Kötü huylar birer birer bırakılmalı, mümkün olduğunca dünya sevgisi gönülden çıkarılmalı, tevbe ve istiğfara devam edilmelidir. Sâlik, her zaman Yüce Allah'ın emirlerine koşmalı, haram kıldığı şeylerden de uzak durmalıdır. Takvâ ehli olmalı, Allah korkusunu aklından çıkarmamalıdır. Üzerine düşen ibadet, zikir ve diğer meşru vazifelerini sebepsiz geciktirmemeli, bu vazifelerini bir yerden bir yere, bir vakitten diğer bir vakit'e geçirmemelidir. Tembellikten ve uyuşukluktan çok sakınmalıdır. Sülûk yolunun afatı tembelliktir. Sâlik, üzerine düşen hizmetleri yerine getirmede çok gayretli ve dikkatli olmalıdır. Vaktin, çok kıymetli bir hazine ve onu boşa geçirmemek gerektiğini salik çok iyi bilmelidir. Tasavvuf yolunun büyükleri derler ki: "Sâlikin Allah yolunda kendisini felakete sürükleyecek felaketler çoktur. Bu felaketlerin başında zamanı boşa harcamak gelmektedir.” sözleriyle zamanın ne kadar kıymetli bir hazine olduğunu belirtmişler ve buna son derece dikkat edilmesine vurgu yapmışlardır (Kuşeyrî, 1997: 65; Aktepe, 29).

\section{SONUÇ}

Abdulhâlik-i Ğucduvânî bugün Nakşibendîliğin esasları diye bilinen on bir temel düsturu ortaya koyan üstattır. Farsça olan sekiz prensibi, Ğucduvânî ortaya koymuş, Arapça olan üç prensib ise Bahâuddîn Nakşbend tarafından bina edilmiştir Bu prensiplerin esası; "Kalbe gelip onu meşgul eden her şeyi oradan çıkarıp atmak ve onu daima Allah-u Teala ile meşgul hale getirmek"tir. Ğucduvânî’nin ortaya koyduğu sekiz prensip, Hâcegân ve Nakşbendiyye tarîkatlarında seyr-u sülûkun temel kâideleri olarak kabul edilmiştir. Ğucdüvânî kurduğu tarîkatta cehrî zikir, semâ ve halvete yer vermeyerek tasavvufî eğitimde yeni bir usûl takip etmiş, ayrıca sünnete sarılmak ve bid'atlardan uzaklaşmaya ısrarla vurgu yapmıştır.

Diyarbakır da yaşamış olan ve Nakşî-Hâlidî çizgisinde yetişmiş olan Abdurrrahman Aktepe'de bağlı bulunduğu tarikat müessesesi tarafından îrâd edilmiş olan ve asırlar boyunca izinden gidilmiş olan bu prensipleri hayat gayesi edinmiş, müridlerine öğretmiş ve eserlerinde yer vermiştir.

On bir esasın sonucuna bakacak olursak genel olarak şunları söyleyebiliriz: Mürîd, içinde bulunduğu zamana muttalî olmalı ve zamanını kontrol altında tutmalı, zamanını gafletle mi, yoksa şükre layık bir uyanıklık ve huzurla mı geçirdiğini düşünmelidir. Mürîd, 
hafî zikir esnasında sayısına riayet etmeli, zihnini dağınıklıktan kurtarmalıdır. Zikirde asıl gaye, zikri yapılan Allah-u Zülcelâl ile kalbin huzurudur, manevi beraberliğidir. Ancak böyle yapıldığı takdirde, zikrin faydası görülür. Anlatılan fayda: "La ilâhe" (ilah yoktur) nefyetmek, yani reddetmek esnasında, beşeri varlığın bitip tükenmesidir. "İllallah" (ancak Allah vardır) isbatı esnasındaysa, ilahî cezbelerin doğuşudur. Bu hal, (ledünnî) ilim mertebelerinin ilkidir.

Mürîd, kalbin yaptığına vâkıf olmalı; zikreden, zikrini yaparken kimi zikrettiğine yakînen muttalî olmalıdır. Zikreden kimse, zikir esnasında kalbini mülâhaza etmelidir. Yani haline, zikirle iştigaline ve zikrin mefhumunu (manasını) mülahaza ettiğine muttalî olarak, kalbinde gaflete kesinlikle yol bırakmamalıdır. Zikrettiği sözlerin manasını düşünerek ve şuurunda olarak zikir etmelidir. Aklı başında bir sâlik, alıp verdiği nefeslere dikkat etmeli, onları gafletten korumalıdır. Böyle yaptığı takdirde; kalben, Allah-u Zülcelâl ile huzurda olur. Zikir yapan kişi zikri esnasında gafletten sakınmalı ve zikrini yaptığı zatı mülâhaza etmelidir. Bu mülâhaza ise kişiyi yaptığı zikrin esas tecellisine götürür.

Mürîde yakışan odur ki, yürürken gözleri ile ayaklarını izlemeli, etrafa dalmamalıdır. Etrafa dalmak, kalbe hicap (perde) getirir. Sâlik bir mürşide intisâb ettikten sonra, mürşidinin emirleri doğrultusunda zâhiren ve bâtınen Allah-u Zülcelâl'e yönelmeli, hicret etmelidir. Sâlike yakışan, kalben Allah-u Zülcelâl ile huzurda olup halk içinde olduğu halde, onlardan ayrı gibi yaşamalıdır. Mürîd, murâkabe mertebesine erdikten sonra, "Nefy-i isbât" yani: "Lâ ilahe illallah," zikrini belli bir miktar dille yapmalıdır. "Nefy-i İsbât" zikrinin belli mertebede dille yapılması şart sayılmıştır. Zira, kalpler anasıra (unsurlar) bağlı olduğundan, anasır gibi paslanır. Anlatılan "Nefy-i İsbât" zikri yapılınca, pası gider. Murâkabe mertebesine çıkar, müşahede mertebesine erer.

Mürîd "Nefy-i İsbât" zikrinin manasını kalbe yerleştirir. Zikri yapan kimsenin kalbine tevhid sırrını getirir. Böyle yaptığı takdirde, bütün yaratılmışların varlığı nazarında silinir, zuhur yerlerinde, mutlak vâhid olan Zât'ın varlığı kendisine zâhir olur. Mürîde düşen odur ki; zikrini yaptığı zaman, "Nefy-i İsbât" manasını düşünerek, kalbine sahip olsun. Böyle yapmalı ki; oraya yersiz hatıralar girmesin. Oraya yersiz hatıralar girince, zikrin neticesi hasıl olmaz.

Mürîd, zikrini ettiği Zât'ın zikri anında, kalbini huzurda tutarak korumalıdır, bu da ancak "Nefy-i İsbat" zikrini nefesini tutarak yaptığı zaman olacaktır.

Netice olarak, mürid şunu bilmelidir ki zikir, murâkabe, sohbet, râbıta ve Yâd-Daşt diye anlatılanlardan hasıl olan huzur manası, hakikatte birdir. Kaldı ki huzur, Zât-1 Ehadiyyet 
nurlarını müşâhede den ibarettir; ancak şekilleri değişiktir. Bu değişik durumu ise ancak havâs zümresi zatlar bilirler.

\section{KAYNAKÇA}

El-Aclûnî, İsmail b. Muhammed, (1352). Keşfu'l-Hafâ ve Muzîlu'l-ìlbâs amma İstehere mine 'l-Ehâdîs alâElsineti'n-Nâs, Dar-u İhyâi' 't-Turâsi'l-Arabi, I, Beyrut: Dar-u İhyâi't-Turâsi'l-Arabi, no: 1102.

Arap-zâde, Muhammed, Mîzânu't-Tarîk, Süleymaniye Ktp. Hacı Mahmud Efendi, no. 6542/2.

Aktepe, Abdurrahman, Risâletu'l-Edeb ve'l-Âdâb.

Ali Sâfî b. Hüseyin Vaiz el-Kâşifi, (1256). Reşahât-ı Ayni'l-Hayât çev. Ma'ruf b. Şerif, İstanbul

Beyhâki, Şuâbu'l-Îman, I, 396, 522.

Buhârî, Ahkâm, 21.

Büyük İslam ve Tasavvuf Önderleri, (1983). İstanbul: Vefa Yay.

Câmî, Abdurrahman, (1995). Nefehâtu'l-üns: Evliya Menkıbeleri, çev. Lamii Çelebi, haz. Mustafa Kara, Süleyman Uludağ, İstanbul: Marifet Yay.

Cebecioğlu, Ethem, (2005). Tasavvuf Terimleri ve Deyimleri Sözlüğü, İstanbul. Anka Yay.

DİA, İslam ansiklopedisi, (1997). XVI, İstanbul.

Gündüz, Gümüşhânevî, (1984). Ahmed Ziyâuddîn, Hayatı, Eserleri, Tarîkat Anlayışı ve Hâlidiyye Tarîkatı, İstanbul: Seha Neşriyat.

Harîri-zâde, Muhammed Kemaleddin, Tibyân-u,Vesâili'l-Hakâik fí Beyâni Selâsili't-Tarâik I, Süleymaniye Ktp., fatih, no. 630-632, İstanbul.

Hazînetu'l-Asfiyâ, I, 530.

İrec Efşâr, Kandiyye, 6-16.

Kenzu'l-Ummal, 16/33951.

Korkusuz, M. Şefik, (1997). Tezkire-i Meşâyihi Âmid, İstanbul.

Kuşeyrî, er-Risâletu'l-Kuşeyriyye, (1997). Tahk. Abdulhamid Baltacı, 3. Bas., Beyrut: Daru'l-hayr.

Lâmiî, Çelebi, Nefehâtu'l-Üns, çev. Târih-i Mollazâde, s. 46.

Muhammed b. Abdullah Hânî, (1976). Âdâb, trc. Abdulkadir Akçiçek, İstanbul.

Muhammed-i Semerkandî, Ebu Abdullah, (1273). Muhtasaru'l-Velâye, çev. Neccar-zâde Mustafa Riza, İstanbul.

Mustakim-zâde, Şerîatu't-Tarîka, Süleymaniye Ktp., Pertev Paşa, no: 625.

Özaydın, Murat, (2009) Şeyh Abdurrahman Aktepe, Hayatı, Eserleri, Görüşleri, İstanbul: Cihan Yay.

Saîd-i Nefîsî , Risâle-i Sâhibiyye

------Ferheng-i İrân, Zemîn, Risâle-i Sâhibiyye (1953) I.

------Ferheng-i İrân, Zemîn, (1954). Makâmât-1 Abdulhâlık-1 Ğucduvânî ve Ârif Rivgerî.

----- Ğucduvânî, Risâle-i Sâhibiyye, 95-96.

Sirhindî, Ahmed Fârûkî, (1853). Mektûbât-ı İmamı Rabbânî, çev. Müstakim-zâde Süleyman Sa'deddin, Litoğrafya Matbaası, I, no: 21, 206, 290.

Şimşek, İbrahim Halil, (2004). Osmanlı'da Müceddidîlik, (XII-XVIII. Yüzyıl), İstanbul: Suf Yay.

Tokâdî, Mehmet Emin, İş̧âdu's-Sâlikîn, Çorum: Hasanpaşa Ktp., no. 772. 
------ Şerh-i Kelimâtı Hâcegân, Millet Ktp. Ali Emiri-Şer'iyye, no. 832.

------- Risâle fî Hakkı Sülûki 't-Tarîkati'n-Nakşbendiyye, Millet Ktp., Ali Emiri-Şer'iyye, no. 1018.

Tuhfetu't-Tullâb Hidâyeti'l-Ahbâb, Millet Ktp. Ali Emiri-Şer'iyye, no. 1018.

------ Şerh-i Kelimât-ı Hâcegân, Millet Ktp. Ali Emiri-Şer'iyye, no. 832.

Topbaş, Osman Nuri, (2006). Imandan İhsana Tasavvuf, İstanbul: Erkam Yay.

Trabzonî, Silsiletu'l-Hâcegân fî ÂdâbiUbûdiyyeti'l-Âyân, Süleymaniye Ktp. Şazeli Tekkesi, no. $158 / 10$.

Uludağ, Süleyman, (1991). Tasavvuf Terimleri Sözlüğü, İstanbul: Marifet Yay. 